University of South Florida

DIGITAL COMMONS

Digital Commons @ University of

@ UNIVERSITY OF SOUTH FLORIDA

South Florida

Academic Services Faculty and Staff

Publications

Tampa Library

$9-11-2015$

\title{
Copyright Instruction in LIS Programs: Report of a Survey of Standards in the U.S.A.
}

\author{
LeEtta M. Schmidt \\ University of South Florida, Imschmidt@usf.edu \\ Michael C. English \\ George Mason University
}

Follow this and additional works at: https://digitalcommons.usf.edu/tlas_pub

Part of the Library and Information Science Commons

\section{Scholar Commons Citation}

Schmidt, LeEtta M. and English, Michael C., "Copyright Instruction in LIS Programs: Report of a Survey of Standards in the U.S.A." (2015). Academic Services Faculty and Staff Publications. 168.

https://digitalcommons.usf.edu/tlas_pub/168

This Article is brought to you for free and open access by the Tampa Library at Digital Commons @ University of South Florida. It has been accepted for inclusion in Academic Services Faculty and Staff Publications by an authorized administrator of Digital Commons @ University of South Florida. For more information, please contact digitalcommons@usf.edu. 


\title{
Copyright Instruction in LIS Programs: report of a survey of standards in the
}

\section{U.S.A.}

\begin{abstract}
This article will detail the results of a survey distributed within the United States of America to professionals working in academic, public, school/media, and special libraries that asked respondents to rate their daily copyright and intellectual property knowledge needs vs. their actual knowledge and education in this area. The results were then compared with an analysis of course content in current ALA accredited LIS programs in the U.S. gathered from online course descriptions to determine whether there is evidence pointing to a need to alter the curriculum of LIS programs to better prepare graduates for the copyright and intellectual property demands they will face on the job. The combined data will inform Library Science colleges and educators as to whether an instruction deficit exists in their current curricula and will give these colleges and educators data to support the development of new programs.
\end{abstract}

Keywords: Copyright, Intellectual Property, education, 


\section{Introduction}

Demands on libraries and library professionals routinely change, but the curricula of many Library and Information Science (LIS) programs do not necessarily keep pace. The Association of College \& Research Libraries' Research Planning and Review Committee's Environmental Scan of academic libraries in the U.S. (2013) forecasts that "many librarians and information professionals will re-envision their roles and define new opportunities" in the coming years, and that "anticipating and preparing for new roles and how these roles can expand and evolve over time will be key to an enduring, engaged, and thriving profession in the future" (p.5). What is the responsibility of LIS programs to anticipate these changes and adjust curricula accordingly to help students start preparing for these new roles prior to graduation?

This study examines this question from the perspective of evolving copyright and other intellectual property (henceforth collectively referred to in this article as "copyright / IP") knowledge demands on library professionals to determine whether there is a solid need to alter the curricula of LIS instruction to better prepare graduates for the demands they will face on the job. In speaking to aspects of intellectual property beyond copyright, we are not speaking to in-depth trademark and patent expertise, but rather to the knowledge needed to expertly administer point IV of the Code of Ethics of the American Library Association, which states, "We respect intellectual property rights and advocate balance between the interests of information users and rights holders" (American Library Association, 2008).

There is much evidence that points to an expanding need for librarians and library professionals to hold increasing levels of copyright / IP expertise. In ACRL's 2012 Top Trends in Academic Libraries, three of its top 10 trends - digital collection, preservation and management; new scholarly communication and publishing models; and a just-intime model of information access and provision - all point towards a growing need for copyright / IP and licensing knowledge within and across the library. Likewise, in its 2012 Code of Best Practices in Fair Use for Academic and Research Libraries, ARL points out that "copyright law affects the work of academic and research librarians 
pervasively and in complex ways" (p. 1). These affirmations of increasing copyright / IP complexities within the library were furthered with ACRL's 2014 Top Trends report which included evolving open access and open educational options, device-neutral access and delivery, and the growth of digital humanities, all of which have very tangible copyright / IP implications within the library.

In their 2013 ACRL report, Common Ground at the Nexus of Information Literacy and Scholarly Communication, Davis-Kahl \& Hensley stated that academic librarians must add copyright and intellectual property literacy to their knowledge base if they are to be equipped to give users the guidance they need. Gathegi and Burke (2008), discussed in more detail later, stated that information schools must provide students with instruction on these issues before they enter the workplace. They pointed to the increasing convergence of the fields of information and law as the impetus for their study into how LIS programs are approaching this convergence, and specifically cited the increasing centrality of intellectual property rights, complex database licensing issues in libraries, and information liability issues. They stated that "robust programs in information schools have to provide their students with some solid grounding on these information law issues, before they graduate."

To investigate the current instruction provided to LIS students, data from the American Library Association-accredited LIS programs was analyzed for any courses regarding copyright / IP content. This data was used as background for a nationwide survey of librarians and library professionals asking about levels of copyright / IP instruction received while obtaining their MLS degrees, and the level of copyright / IP knowledge required of them on their jobs. The aim of the study was to assess the current level of copyright / IP education offered in U.S. LIS programs, compare this with self-reported copyright instruction and copyright demands data from practitioners, and develop possible recommendations for the future directions of copyright education in LIS programs. 
While the current study focuses on copyright / IP education in U.S.-based LIS programs and copyright / IP knowledge required of U.S.-based LIS professionals, it is worth mentioning as an aside that the challenges of keeping LIS curricula current enough to create graduates who have sufficient training to meet the demands of the workplace is a worldwide challenge, one that has been exacerbated by the swiftness of change in the digital environment. Likewise, the question of whether more copyright / IP training is required in the field is not a U.S.-specific question, but rather one that has been asked internationally for at least the last decade. In 2003, Swain argued for the need to incorporate more legal content into LIS curricula in India and proposed that LIS programs add an elective, copyright-centered course. More recently Burnett (2013) reported on the findings of curriculum review workshops of 12 developing African countries conducted between 2008 and 2012. Among the findings were that LIS curricula in Ethiopia were not adequately addressing copyright issues, and that employers in Uganda and Kenya with LIS graduates on staff found that most lacked adequate knowledge of copyright related to electronic resources. A final example is Johnston and Williams (2015) who conducted a skills and knowledge needs assessment survey among library professionals, LIS students, and library managers in Qatar (which has an international professional LIS population from European countries, Arab countries, and the U.S.). The respondents listed "copyright training" as the secondmost important area for the professional development of librarians in Qatar, and also listed this topic as among the most needed topic to be covered in professional development workshops and conferences.

\section{Review of the Literature}

To our knowledge, no comprehensive study exists in the literature that investigates copyright / IP instruction in LIS programs vs. practitioner needs of copyright / IP knowledge by synthesizing LIS course descriptions with survey data from practitioners. However, there has been much research separately into both LIS course content for specific courses and the copyright / IP demands of library professionals. Most of the course content studies investigated specific subjects of LIS education, and we drew on the methodologies of some of these studies to conduct our course content analysis. 
In 2004, Buchanan investigated the teaching of Information Ethics in ALA-accredited LIS programs. Buchanan searched LIS program websites to see which among them offered a graduate-level course focused on ethics, examined current syllabi for the ones that did, and reviewed content covered and pedagogical approaches. In his analysis, Buchanan considered the overlap between legal and ethical issues, and asked if ethics classes should be the place where students learn about the principles of fair use, or if such classes should only speak theoretically about the importance of the principles of fair use and the impacts on librarianship. This potential crossover between ethics and copyright law discussions, and ethics and copyright law classes, led us to include "ethics" in our search terms when searching course descriptions for copyright and IPrelated content, which will be discussed in more detail later. Buchanan concludes by recommending a standalone ethics course, arguing that ethics cannot fit into existing courses.

In 2009, Sutton investigated the level of continuing resources (serials) instruction in LIS curricula by conducting a content analysis of online course catalog descriptions, syllabi, and other elements of the curricula. He also looked into "perceived impediments" to altering LIS curricula to increase continuing resources instruction that are cited in the literature. Sutton cites Weber's 1975 study on continuing resources education in LIS curricula, where Weber states that "to expect a person to cope with the convoluted reality in the serials world without ever having even heard the word "serials" is cruel, unprofessional, wasteful, and foolish" (p.79). The authors of this study contend that one might make the same observation about copyright today. In his study, Sutton tallied the number of instances where continuing resources were explicitly or implicitly included in course descriptions, syllabi, course schedules and requirements, and degree requirements. The level of coverage or non-coverage of continuing resources in classes was determined by searching for such terms as "serial," "continuing resource," "journal," or "electronic resource," as well as some broader terms that were examined in context to determine whether they constituted a continuing resources component. We mimicked a part of Sutton's methodology by searching course descriptions for 
"copyright" and related terms to determine levels of coverage and non-coverage of copyright / IP related issues in classes. Sutton points to evidence in the literature that supports his concluding recommendation of the need of a required continuing resources component in LIS curricula.

McCaslin (2009) argued to recognize the importance of access services-typically defined as circulation, course reserves, interlibrary loan, document delivery, and collection maintenance-as a component of librarianship, and the need for it to be recognized as a necessary component of LIS education. Cataloguers, McClaskin underscored, organize information, reference librarians interpret information, and access services librarians deliver or connect users with information, all equally important and valuable functions. The author examined course content by examining the websites and course descriptions for U.S. News and World Report's top 30 ranked ALA-accredited LIS schools. No program was found to have a course devoted to access services. The study did find that copyright was an area "investigated by many programs" (489). McClaskin argued that, given the establishment of access-services-focused scholarly journals and the importance of access services in performing the critical function of connecting users with resources, the significance of access services within the field of librarianship was not adequately represented in LIS curricula. She argues these factors justify the creation of an Access Services course, which should be an elective, much like courses such as archives or children's reference resources.

In 2010, Bailey did a cross-referential analysis that examined the content of courses through an analysis of the subject matter focus of course syllabi. He examined the most covered subjects, pedagogical methods used, assignments given, and textbooks, and then compared these with proficiencies cited in the literature. According to Bailey, this was the first study examining the actual content of LIS courses to compare with the proficiencies and skills cited in the literature as being necessary for a successful academic librarian. He also compared the data from the syllabi analysis with the results of an ACRLog survey by Stephen Bell (2008) which asked readers to classify 30 subjects as essential, important, or marginal to a class on academic librarianship. The 
30 given categories supplied by Bell did not include "copyright" or "intellectual property," but did include "scholarly communication," which was one of the most selected categories and was the only supplied topic that could have been considered to include copyright / IP. There was also a write-in option, and "copyright" was among the most often written-in choices. Bailey concludes that due to the large number of desired proficiencies, it is not probable that a single course in academic librarianship could cover all of the topics needed.

Investigating the copyright demands of library professionals in 1989, Dragich examined the possibilities of information professionals being subject to malpractice liability by examining hypotheticals that had been posited in the literature, introducing new ones, and looking at real court cases that could apply to potential information malpractice lawsuits. Dragich highlighted the change of the librarian role from caretaker and dispenser of books and resources to a role that today is "more often to advise the client on information needs (268)," and he likened the faculty/librarian relationship to one of client/professional, where "the client entrusts his/her needs to the professional because the professional has knowledge or expertise the client lacks (268)."

Gathegi and Burke (2008) pointed to the increasing convergence of the fields of information and law as the impetus for their study into how LIS programs are approaching this convergence. Among the changes they cited are the increasing centrality of intellectual property rights, complex database licensing issues in libraries, and information liability issues. They stated that "robust programs in information schools have to provide their students with some solid grounding on these information law issues, before they graduate. This is especially so because intellectual property, security, and privacy issues are likely to take center stage in the field of information science for a long time in the foreseeable future (1-2)." The authors looked at ALISE member schools in the U.S. and Canada and also included 4 non-ALISE i-schools to analyze (1) self-reported data from the 2004 LIS Educational Statistical Report, (2) results of a questionnaire sent to LIS school Deans and Directors, and (3) curricula information posted on the schools' websites. The study looked at intersections of law 
and how law was being presented in the programs, and found that overall, the schools are engaging with the increasing importance of covering law-related issues. Also among the findings was that copyright / IP courses appeared only once in every 20 information schools. "A surprising finding," the authors stated, "given the current issues in the field, was the paucity of courses in intellectual property/copyright ... this may be explained . . . by the fact that these issues are often covered in information policy courses (16-17)."

Albitz (2009) looked into the organizational placement of current copyright education structures in $11 \mathrm{CIC}$ schools by interviewing the person responsible for copyright management at the institution to determine whether those assigned to these duties had the resources and authority to effectively act on these issues. "Librarians have," the author pointed out in his rationale, "either intentionally or by default, become clearinghouses for information about appropriate use of copyrighted content, despite the fact that very few librarians are trained in the law (429)." Based on an analysis of the interview results, the author proposes that hiring an intellectual property attorney is the most important element to creating a well-respected copyright program within a university, primarily because the credentials create a perceived level of authority and neutrality. Regardless of whether such a position is assigned, the author argued that those responsible for copyright and copyright education within the university must have the support and resources needed to carry out their duties effectively.

Chu (2010) reviewed changes and developments in LIS education in the first decade of the $21^{\text {st }}$ century, based on a review of the literature and on his own 2006 content analysis of 45 ALA-accredited LIS programs in the United States where he analyzed 2,757 course in 45 programs. Chu noted three major developments in LIS education: the growth of distance education, the emergence of iSchools, and the growing chasm between education and practice. In his 2006 content analysis study, Chu found 233 required courses in the 45 programs. None of 233 required courses found was centered on copyright and/or intellectual property. He did find that five of the courses focused on information ethics and/or information policy-courses that may have included copyright / IP content. Of the 292 courses identified as new courses, those that had high 
frequencies included Digital Libraries, 27 instances, and website design and applications, 24 instances; those that showed with lower frequencies included Usability, 3 instances, and Natural Language Processing, 4 instances; and there were 79 new courses that each appeared in only one program's curriculum. Cyberspace Law \& Policy-a course that most certainly involved copyright /IP content-appeared 11 times, and Chu also found many instances of "Special Topics" courses, which did not specify their subject content.

Hansen, Cross, \& Edwards (2013) surveyed 110 ARL institutions to determine how institutions were managing copyright compliance with regard to e-Reserves. The authors pointed out that decisions related to copyright and other aspects of the law such as privacy are often made by librarians who do not have a complete understanding of the issues, since few gain graduate-level training in these areas. Thirty-five institutions responded to their survey. Of those, 32 reported that they made items available to students in electronic format via an e-Reserves system. Thirty of these had policies in place to evaluate uses, more than half of these responded that they had evaluated or updated their policy within the previous year, and more than 80 percent responded that they had done so within the previous five years. In their conclusion, the authors state that while the existence of policies indicate that institutions are concerned with being compliant with the law, "many institutions have limited means for managing and assessing their institutional practices with respect to e-Reserves services (77)."

Charbonneau and Priehs reported in 2014 on the results of a national study where they looked into the experiences of academic librarians and library staff in providing copyright services and answering copyright-related questions by asking about their expertise and comfort levels in answering these questions, the extent that partnerships exist across the campus for them to reach out to as resources, and any training needs they felt they needed. The authors cite as justification for their study a 2013 ACRL article on scholarly communication and information literacy (Davis-Kahl \& Hensley), a 2013 Educause report stating the need for increased copyright knowledge on campus that MOOCS will require (Educause), and a body of literature that points to academic 
libraries becoming more involved with copyright issues due to considerations linked to course reserves, licensed resources, and assisting faculty with various copyright issues. The authors surveyed academic library workers via listservs and received responses from 226 individuals. A majority of the respondents answered they had handled copyright-related issues and questions, yet just under half reported they felt

prepared to handle such questions. Slightly fewer than half of respondents said they felt comfortable with their knowledge of current copyright policies, and an additional 7.3 percent said they felt very comfortable, leaving about 43 percent feeling less than comfortable. The study put forth several strategies to build awareness and knowledge of copyright-related issues in the academic library workplace such as various training methods, appointing a copyright expert, and collaboration with experts across the campus.

\section{Analysis of Current LIS Programs}

In 2013 - 2014, online course catalogs and course descriptions for the 51 ALAaccredited Master's Programs in Library and Information Studies in the United States were searched for keywords that would or might indicate some level of copyright / IP content. Course descriptions ranged from short, one to two sentence descriptions to fullpage descriptions with expectations, learning objectives, and rationales for inclusion. The keywords used to search were "copyright," "intellectual property," "legal," and "ethic." Ethics in LIS courses typically speaks more to maintaining objectivity, confidentiality of patrons, and resisting censorship pressures; however there is occasional overlap between ethics and copyright issues, so we included the term as a keyword to ensure we did not miss any classes that might touch on copyright / IP issues. Once the courses with these keywords were identified, course titles and descriptions were evaluated individually to attempt to best gauge the level of copyright / IP content in the course. At this point, if the context of "ethic" did not align with the suggestion of any copyright / IP content, and there was no mention of any of the other keywords in the course title and/or description, this was noted and those notations are included in the results that follow. 
Once the courses that did indicate copyright / IP content were identified, these were evaluated to see which of four groups they fell into: (1) required courses dedicated to copyright / IP issues, (2) elective courses dedicated to copyright / IP issues, (3) required courses with a copyright / IP component, and (4) elective courses with a copyright / IP component. Where there were specialization tracks such as archives and records management, or school media specialist, only the general Library and Information Science track was considered when determining required courses.

Our analysis found that no LIS program, at the time of investigation, offered a required course dedicated to copyright. Eleven programs offered an elective dedicated to copyright; ten of these had only one course listed, while the University of Illinois offered three different courses.

Nine programs included a required class with a copyright / IP component. Most of these were Introduction to/Foundations of Library and Information Science courses, and for most descriptions there were only indirect mentions of copyright, such as "...legal and ethical responsibilities of the profession..." or "...legal and ethical issues..." Only three of the nine directly mentioned "copyright" and/or "intellectual property." Four of the nine were also among the schools that offered an elective course dedicated to copyright / IP, of which one was among the aforementioned three which mentioned "copyright" and/or "intellectual property" directly. In total, 16 programs offered an elective dedicated to copyright / IP and/or a required course with a possible copyright / IP component mentioned in the description and, of these, 13 offered courses with an elective dedicated to copyright / IP and/or a required course with a likely copyright / IP component mentioned in the description. These 13 schools represent just over 25 percent of the total number of U.S. ALA-accredited LIS programs at the time of the analysis.

For the last category-elective courses with a copyright / IP component-42 programs had at least one elective course containing at least one of the keywords ("copyright," 
"intellectual property," "legal" or "ethical") mentioned in the course description. Of these, the majority (35) had a direct mention of "copyright" or "intellectual property" in at least one course description (Figure 1).

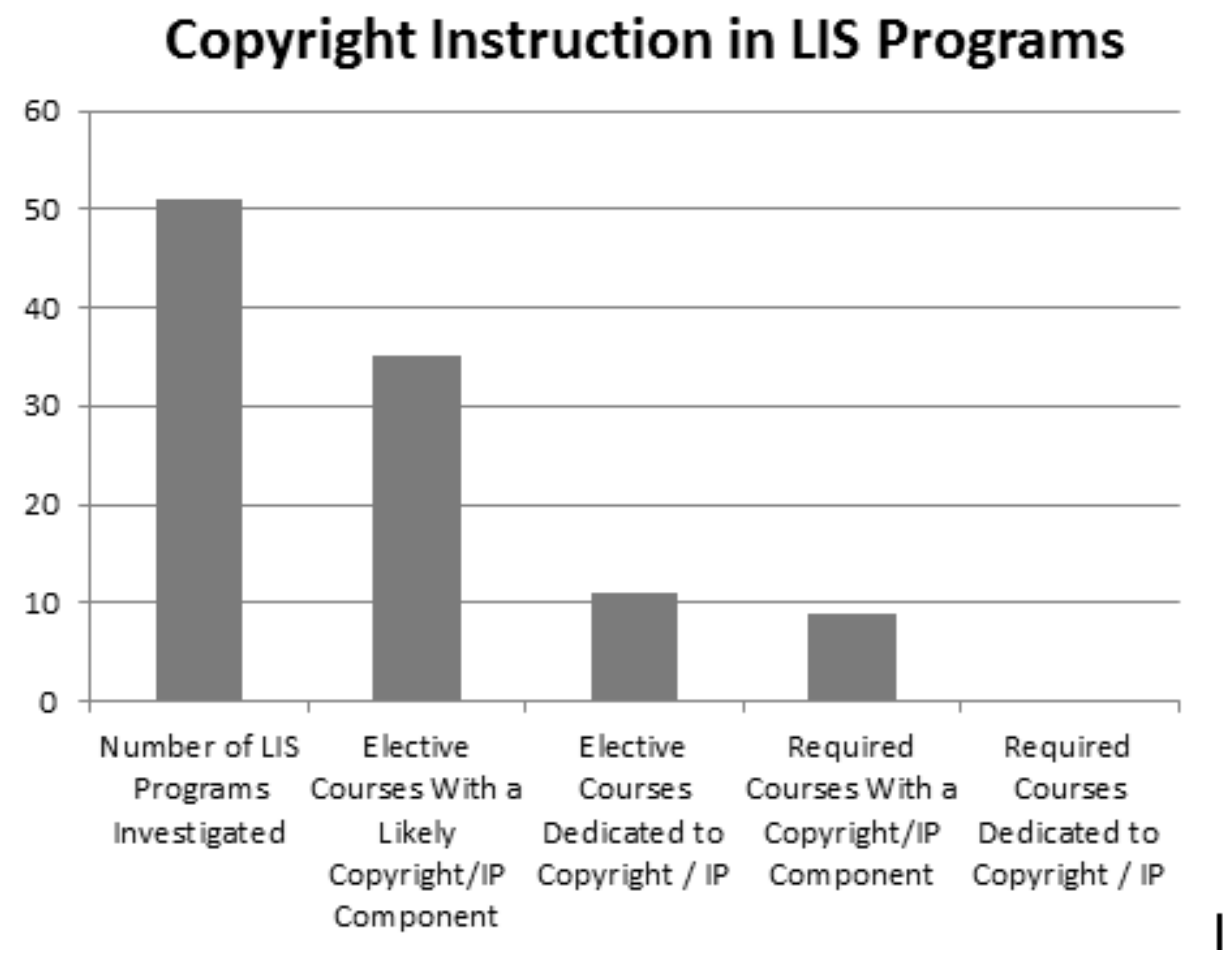

Figure 1

In total, six institutions had no mention of "copyright," "legal," "ethical," or "intellectual property" in any of their required or elective courses: University of Alabama, SUNY Buffalo, University of Puerto Rico, Southern Connecticut State University, University of Tennessee, and Wayne State University.

The limitations of our course content analysis include uncertainty regarding how up-todate the LIS program course descriptions analyzed were, levels of details in course descriptions that varied depending on the program, and a degree of subjectivity in the choice of keywords used to search for relevant content.

\section{Survey Methodology}


Initial work on the project included selecting a sample population of librarians and library professionals who would be requested to participate in the survey. Two separate listsWashington Monthly's college rankings and Library Journal's star public libraries-were consulted to identify top-ranked academic and public libraries. Top-ranked libraries are often perceived by their peers as aspirant institutions. It was hoped that by collecting responses from the staff of top ranked libraries in each field of service, we would be able to more accurately predict the needs of all LIS students for copyright / IP knowledge upon their entering the workforce. Individual contact information was gathered from publicly accessible websites or solicited from a contact person at each library.

In an effort to gain results from and represent libraries of varying sizes and types not included in the two ranked lists, volunteers were also requested from several professional library listservs to send the survey on our behalf. Overall, the survey announcement was sent to 2029 individual emails and 7 listservs. Survey responses were collected for one month before the survey was closed.

Questions were constructed to capture the views of a variety of library professionals on their perceived demand of copyright / IP law knowledge in the library as well as the amount of training they had received, if any, on the subject.

\section{Results}

495 respondents completed the survey. Of those, $82 \%$ were currently working in academic libraries, followed by $9 \%$ working in public libraries. Other respondents worked in school/media, medical, special, state, law and corporate libraries.

When asked if their library employed a librarian or staff member to function as a copyright expert or advisor, a small majority, $59 \%$ of respondents, confirmed that their library did have a copyright expert/advisor on staff. $30 \%$ responded they had no such person, and the remaining $11 \%$ offered a number of scenarios that included being in transition after their expert left, referring issues to a copyright team or committee, 
consulting with the university legal department, or (the most often cited situation) relying on non-official experts who took it upon themselves to be educated and keep up to date on copyright issues.

Websites were the most commonly referenced additional resources that library staff consulted to answer questions on copyright / IP (81\%), followed by library-specific webinars and books on copyright / IP (both 59\%). Local policy manuals and professional journals took third place among the most-referenced additional resources (both 33\%). Listserv discussions, university/general counsel, and interpersonal connections with legal experts either affiliated or not affiliated with their institutions were common responses among respondents who chose 'other' when asked about their most consulted resources for copyright / IP questions.

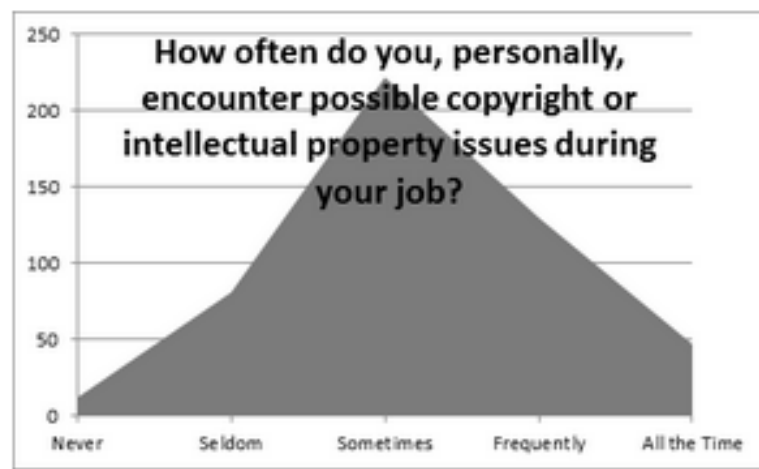

Figure 2

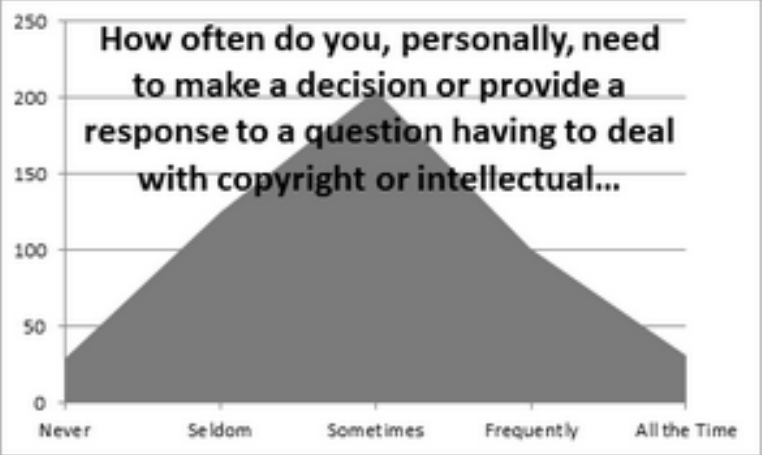

Figure 3

A majority of the respondents answered that they encounter copyright / IP issues with some regularity. $45 \%$ answered sometimes, $26 \%$ answered frequently and $10 \%$ answered 'all the time.' Only 19\% of respondents encountered copyright / IP issues never or seldom (Figure 2).

Respondents were only slightly less likely to have been required to provide answers or to make decisions on questions of copyright / IP. $42 \%$ answered sometimes, $21 \%$ 
answered frequently, and $6 \%$ answered all the time. $31 \%$ of respondents reported that they never or seldom need to answer such questions (Figure 3).

The most often encountered copyright / IP issues while on the job were making copies or scans $(71 \%)$, followed by using copyrighted material in a project or publication (66\%), obtaining permission to use copyrighted material (47\%), and using copyrighted material in the classroom (45\%) (figure 4). Issues provided by respondents who selected 'other' included educating students on their own rights as copyright owners and also on their use of others' copyrighted material, understanding and communicating public performances rights, and posting material to websites, course management systems, and institutional repositories.

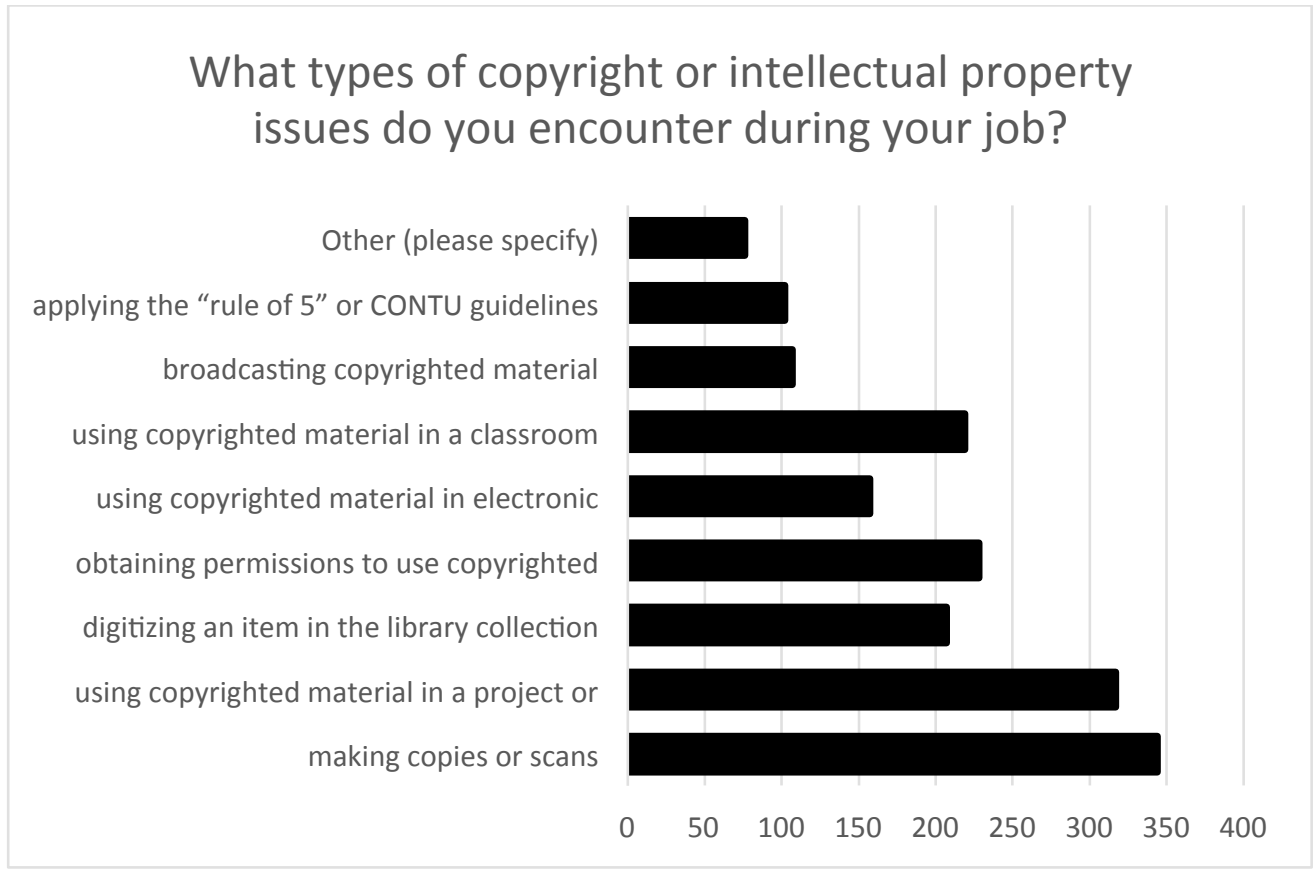

Figure 4 


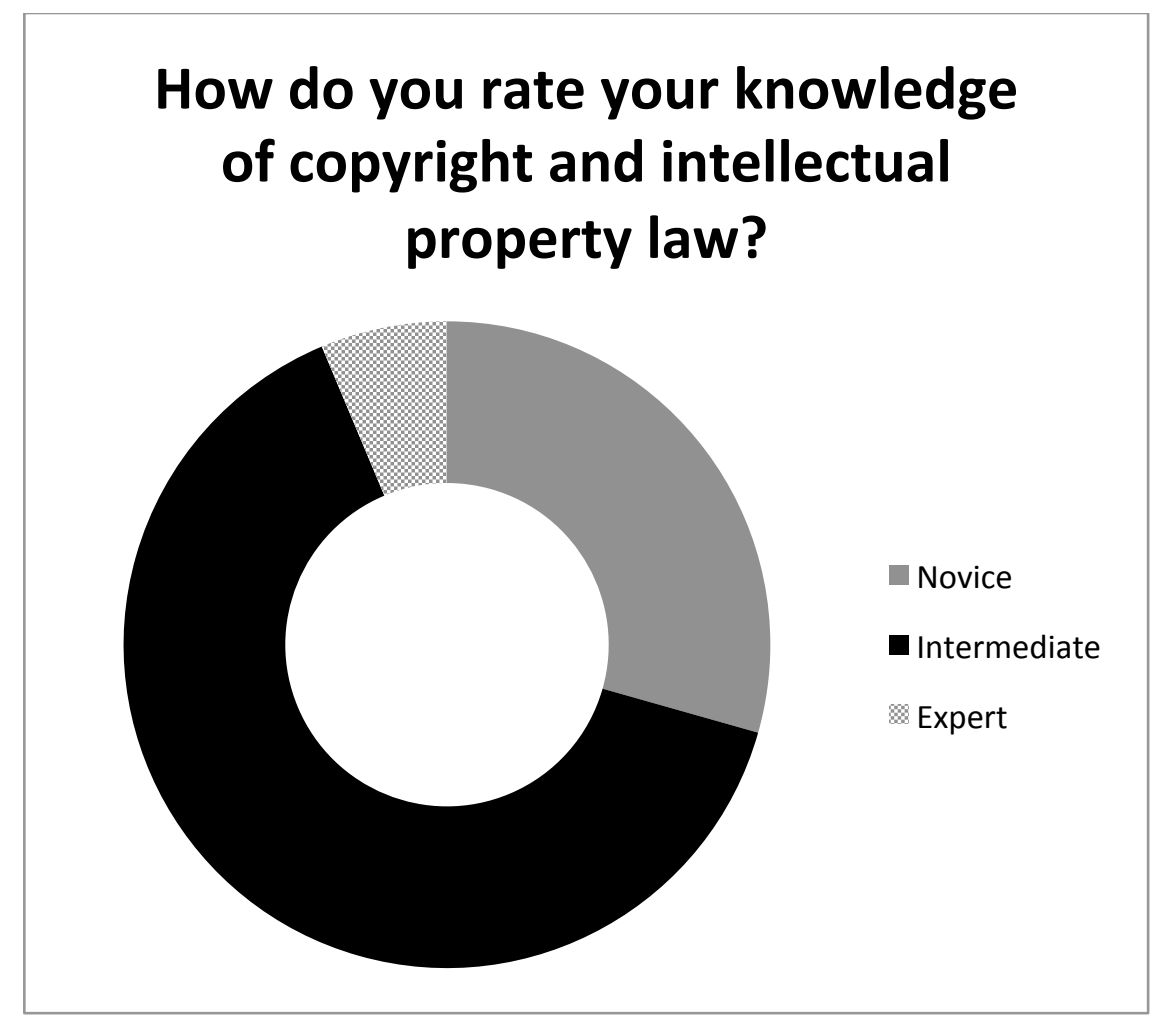

Figure 5

Most respondents, 314 of 487, rated their own level of expertise in copyright / IP law as intermediate (figure 5). Volunteered comments indicated that, for many, their knowledge of copyright / IP laws had come from personal study or previous education and work outside of library science. Other comments highlighted a lack of confidence in their knowledge level, no matter what rating they chose.

When compared to the amount of demand that respondents reported for copyright / IP issues, those that rated themselves as novice were less likely to say they encountered copyright / IP issues frequently or all the time. However, those respondents that rated themselves as expert were the most likely to report a "frequent" or "all the time" demand for copyright / IP knowledge (figure 6). 


\section{Respondent self rated knowledge and demand}

for decisions on copyright issues

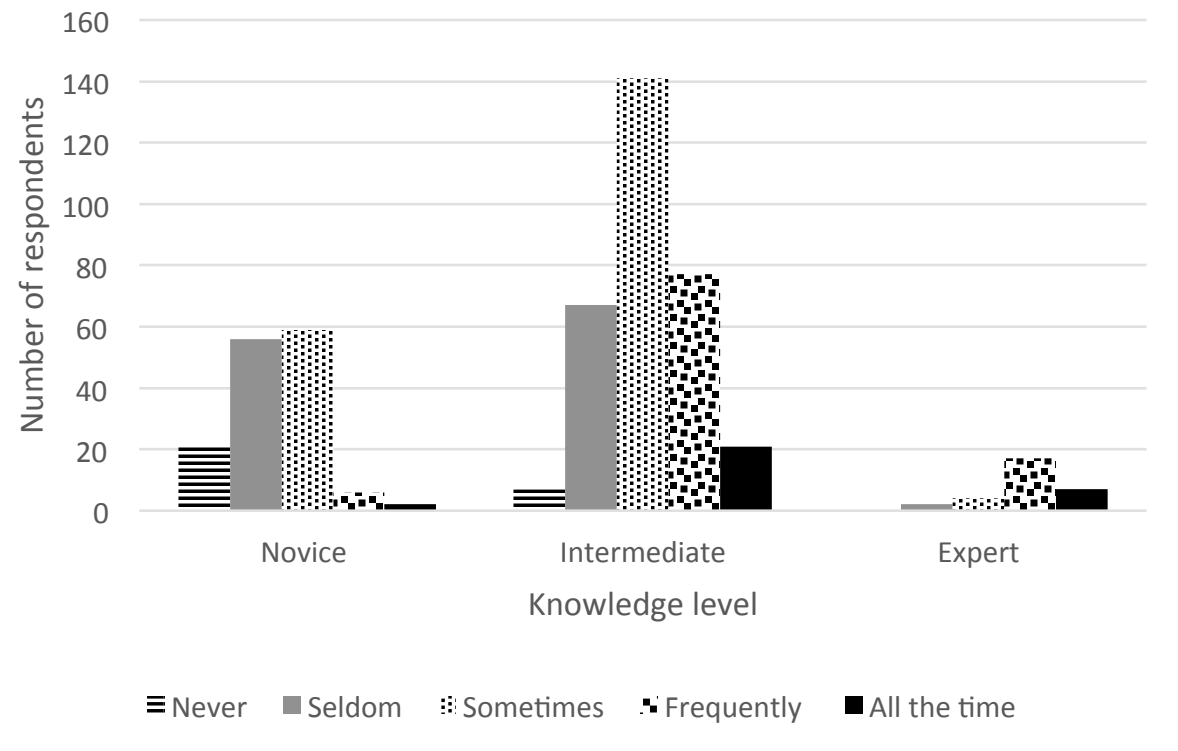

Figure 6

Respondents' volunteered answers were used to correct for a mistake in the survey that excluded "Reference" as a response option to the question "In what area of the library do you work?' After correction, the largest number of respondents chose "Other" and indicated that they worked in several, and sometimes all, of the departments listed. Reference followed with 135 , or $28 \%$ of respondents, then Administration with $12 \%$, and next was Interlibrary Loan with 10\% (figure 7 ).

Library department and library size (as reported by respondents who held all the positions in their libraries) seemed to have no bearing on how often respondents encountered and needed to make decisions on copyright / IP issues. 


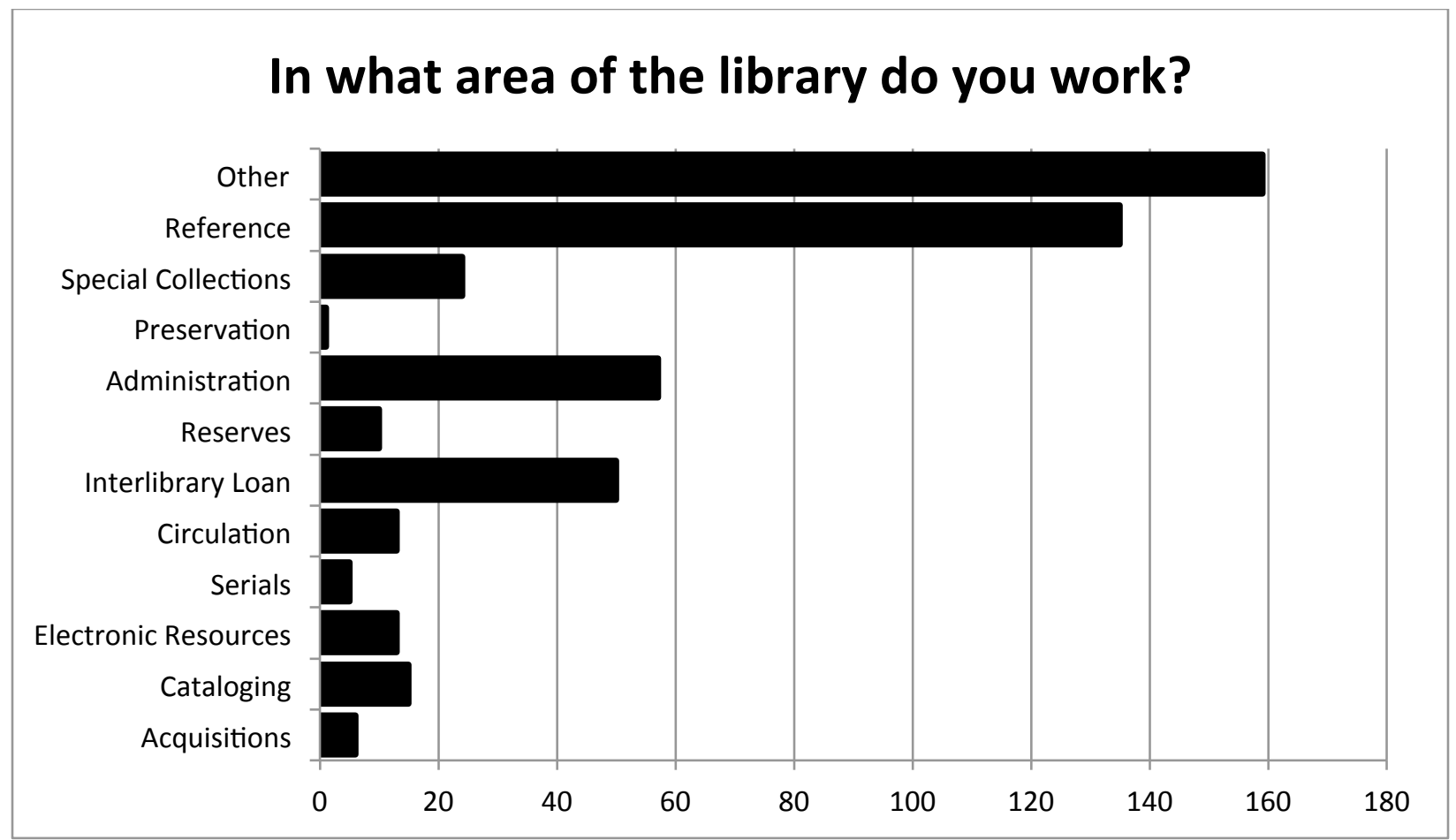

Figure 7

The respondents were asked to rank a variety of library areas, from one to ten, in order of those that require the most copyright / IP law knowledge to those that require the least. Course Reserves and Interlibrary loan received the highest rankings on average, followed by serials/electronic resources and reference (figure 8).

The respondents' answers about which area of the library they thought required the most copyright / IP law knowledge were compared to their answers about which area of the library they worked to see if the respondent's answers favored or disfavored their own area. Only four areas of the library showed any obvious bias.

Not surprisingly, bias was seen in the two areas most highly rated overall to have need of copyright / IP law knowledge: reserves and interlibrary loan. $41 \%$ of respondents who work in interlibrary loan ranked interlibrary loan as the area most in need of copyright / IP expertise. Of those that marked interlibrary loan second or third, 30\% marked course reserves as the first area. $70 \%$ of respondents who worked in reserves 
rated reserves the area most in need of copyright / IP law knowledge, with all other library areas following with no discernible pattern. $46 \%$ of the respondents who worked in cataloging marked cataloging as the area least likely to require copyright / intellectual property law knowledge. $30 \%$ of respondents from special collections reported that special collections was the most in need of like knowledge.

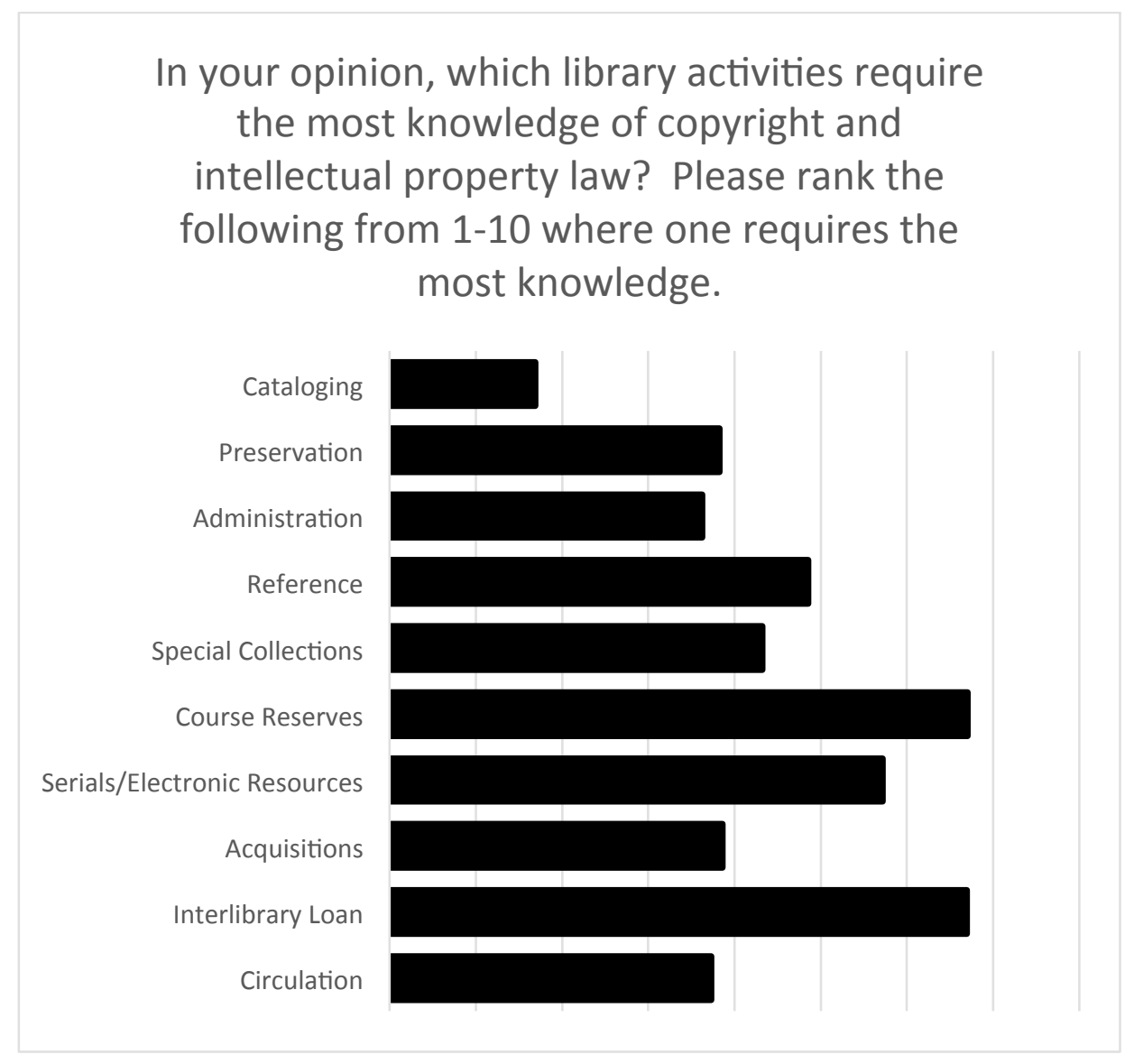

Figure 8

In answer to a question asking how long they had worked in libraries, $46 \%$ of respondents answered 10 years or less, $26 \%$ answered 11 to 20 years, $17 \%$ answered 21 to 30 years, and 10\% reported having worked in libraries for over 31 years (figure 9). 


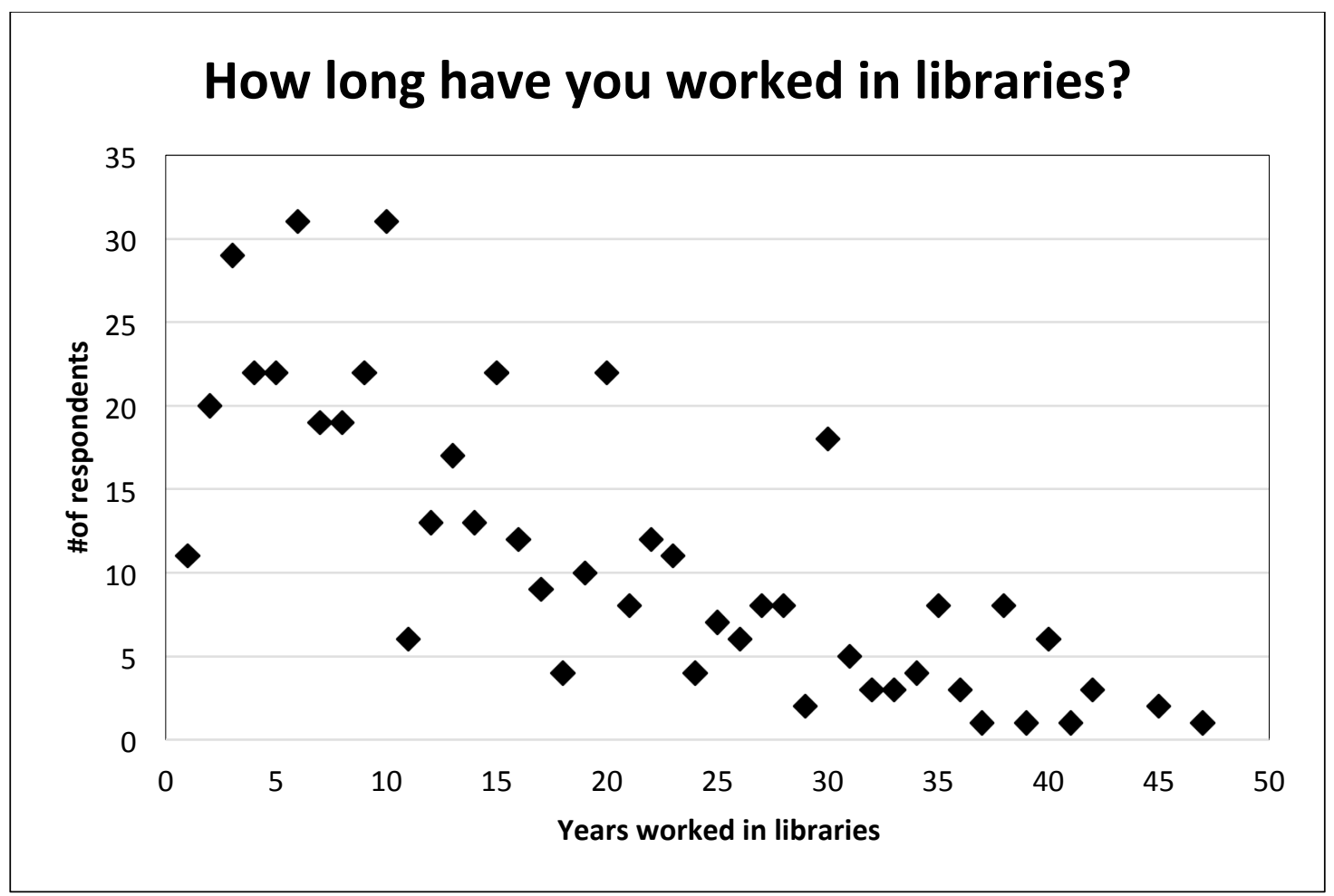

Figure 9

No respondents who reported working in libraries for five years or fewer rated themselves as experts in copyright / IP knowledge. Beyond the five year mark, there did not seem to be any correlation between respondents' self-reported copyright / IP knowledge and the amount of time they had worked in libraries.

The majority of respondents-86\%-have an MLS. The remaining $14 \%$ of respondents encounter and decide on copyright / IP issues with the same rates of frequency as those with an MLS. $48 \%$ of respondents began work in libraries after graduation with their MLS. Of those that worked in libraries before attaining their degree, 6 years was the average time worked before graduation. $9 \%$ of respondents with an MLS held jobs that did not require their degree.

When asked In what year did you graduate with your masters?, 37\% responded that they graduated between 2000 and 2010 , followed by $27 \%$ who responded that they 
graduated after 2010 , and $18 \%$ answering that they graduated in the 1990 s. The remaining respondents received their degree in the 1970s and 1980s (figure 10).

\section{\%Graduates from each decade}

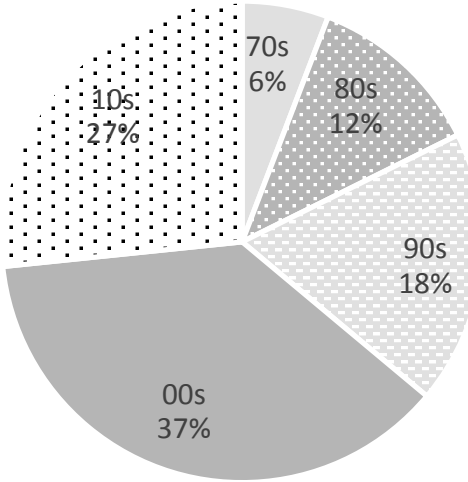

Figure 10

Of the 420 respondents with an MLS, 55\% reported that at least one class they took while pursuing their degree addressed copyright / IP, and 45\% reported that none of the classes they took addressed these topics. Among the comments submitted by those who answered affirmatively, responses such as "very briefly touched on," "very limited," and "only minimally" showed up with some frequency. Those that graduated in the previous 15 years were more likely to have had copyright / IP instruction in their MLS courses (see figure 11). Unsurprisingly, those that did receive copyright / IP instruction while attaining their MLS rated their knowledge of copyright / IP higher than those who did not. 


\section{Did your MLS classes address copyright?}

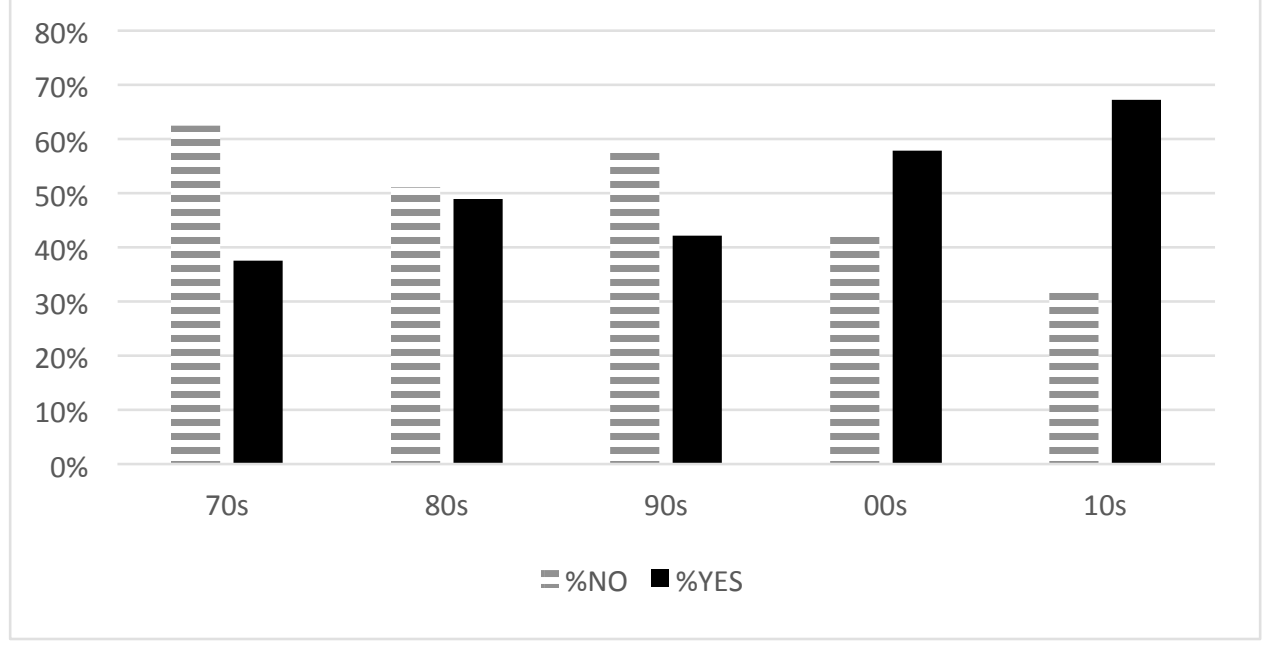

Figure 11

The majority (62\%) of respondents who had received copyright / IP instruction in their program's classes rated the knowledge gained in classes for their degree as either much less or slightly less than needed for their job, 31\% reported that the knowledge gained was sufficient, and only $7 \%$ reported that it was slightly or much more than needed. Since those who graduated in the previous 15 years were more likely to have had copyright / IP instruction in their LIS program classes, their responses to the sufficiency of copyright / IP instruction in their classes were further analyzed. None of these respondents reported that the knowledge they gained was more than needed, and $35 \%$ reported that it was sufficient, which is a small increase over the group as a whole.

$80 \%$ of respondents received no copyright / IP-specific, on-the-job training when they started working in libraries. Volunteered comments indicated that many pursue information and education opportunities independently to increase copyright / IP knowledge.

Respondents were asked to include any additional thoughts on the subject in a final question. Many respondents commented on the additional, self-directed learning they pursued on copyright / IP. Some respondent comments also reflected dissatisfaction 
with current guidelines like CONTU, calling it restrictive and obsolete. However, other respondents commented that they relied on the rules of five and two for their clarity in addressing interlibrary loan copyright issues and wished for similar guidelines in other areas like reserves.

Respondents were also in disagreement about what areas in the library should have instruction on copyright / IP. While some mentioned that all areas of the library experienced pretty equal demand for copyright / IP knowledge, others specified that since only a few departments need to have this knowledge, LIS programs may not be the best place for copyright / IP instruction. Another reason given for keeping copyright I IP instruction out of LIS programs was the high changeability of the subject matter as perceived by some respondents.

Those that didn't see the need for more education on the topic in LIS programs were in the minority. Most respondents reported that additional instruction in LIS programs would be useful to address increased demands for copyright / IP leadership within libraries, patron guidance on copyright issues, and copyright literacy and outreach efforts. Additional focus areas within the library that respondents mentioned as requiring copyright / IP knowledge were scholarly communication, OA publishing, digitization project management, and faculty and student advising.

\section{Discussion}

The prevalence of copyright / IP instruction in LIS programs has risen in the last fifteen years and can be seen to varying degrees in the course offerings of at least 38 out of 51 ALA-accredited LIS programs in the United States. However, two thirds of the graduates surveyed still feel this instruction is insufficient to meet the demands of their workplace. This is not surprising given that no LIS program we examined had a required course dedicated to copyright / IP and only $25 \%$ offered an elective dedicated to copyright / IP and/or a required course with a likely copyright / IP component. 
Interestingly, although a majority of librarians and library staff encounter copyright / IP questions with some regularity, $80 \%$ of the respondents had little on-the-job instruction detailing how to deal with such questions. For the most part, those that encounter the questions are required to provide answers and guidance regardless of how confident (or uncertain) they feel with the subject matter. New areas of focus in libraries, such as scholarly publishing, OA, and digital collection preservation and management, as well as growing areas in academia and higher education like digital humanities and open educational models, are only increasing demand for copyright / IP knowledge within the library.

This demand has been recognized by many. After surveying librarians who had attended his lectures on "Library Copyright 101" asking how often they encountered copyright issues, Harvard University's Copyright Advisor, Kyle Courtney, started a pilot of librarians known as Copyright First Responders to address the increased demand for copyright knowledge and instruction in the academic library setting that the survey results revealed. Participants in the first group of CFR participated in an immersion program on copyright that included lectures, readings, workshops, and guest speakers. The CFR group will help deliver information and will connect people with a university copyright advisor when legal advice is needed (Peet, 2014).

Concerns voiced by some respondents that librarians should steer clear of providing legal advice are echoed by Kenneth Crews in his reaction to Kyle Courtney's First Responders program (Peet, 2014). However, Courtney's program and current literature on copyright needs in the library points to a growing understanding that increase in demand for knowledge and instruction is changing the librarian's role in guiding users through information on copyright. $59 \%$ of respondents reported that their libraries already had a designated copyright expert; additionally, $11 \%$ reported that the designated copyright librarian position was in transition. If, as Charbonneau and Prieh found, only $49 \%$ of these experts felt confident in their ability to answer the questions assigned them (2014), they might fall into the same use of restrictive guidelines and risk management that Adler, Butler, Aufderheide, \& Jaszi pinpointed as impairing "the 
accomplishment of the academic and research libraries' mission" (2010, p1). In addition to the administrative support of academic and research librarians making decisions on copyright called for by Adler, Butler, Aufderheide, \& Jaszi (2010), information school graduates need to have been provided a solid grounding in information law before graduation (Gathegi and Burke, 2008). This is especially important for the large number of respondents whose work straddled departments or who retained positions as the only librarian at a small institution, where on the job training could be even more scarce.

\section{Conclusion}

Although recent graduates of LIS programs in the United States are more likely to have had instruction on copyright / IP issues, this instruction is not widespread enough, nor in depth enough to prepare LIS program graduates for the current demands of the workplace. This lack of preparation, coupled with an absence of guided on-the-job training, leaves librarians unsure of their abilities to competently guide their libraries and their users in the use of copyrighted content. This, in turn, can lead to both misinformation on copyright law and a reliance on strict guidelines, such as the " $10 \%$ rule," that are created separate from the law to manage potential risks using straightforward rules and formulas that consider neither the nuances of copyright law nor competing interpretations of the law. In 2014, the appeals court in the Georgia State case warned in its ruling against these very kinds of one-size-fits-all solutions (Cambridge University Press). It is clear that a firm foundation in copyright / IP laws during their LIS program coursework would be the footing future librarians need to face growing workplace demands in the area of copyright / IP, to institute training programs to create a more copyright / IP-literate library staff, and to create instruction programs for library users towards the same end. It is in the hands of LIS educators to deliver expansive and required coursework in how copyright and intellectual property laws influence the traditional and new library services reported by survey respondents, including scholarly communication, OA publishing, digitization project management, and faculty and student advising.

\section{References}


Adler, P.S., Butler, B., Aufderheide, P., \& Jaszi, P.A. (2010). Fair Use Challenges in Academic and Research Libraries. Association of Research Libraries. Retrieved from http://www.arl.org/storage/documents/publications/arl_csm_fairusereport.pdf

American Library Association. (2008). Code of Ethics of the American Library Association. Retrieved from http://www.ala.org/advocacy/proethics/codeofethics/codeethics

ACRL Research Planning and Review Committee. (2014). Top trends in academic libraries: A review of the trends and issues affecting academic libraries in higher education. College \& Research Libraries News, 75(6), 294-302. http://crln.acrl.org/content/75/6/294.full

ACRL Research Planning and Review Committee. (2012). Top trends in academic libraries: A review of the trends and issues affecting academic libraries in higher education. College \& Research Libraries News, 73(6), 311-320.

http://crln.acrl.org/content/73/6/311.full

ACRL Research Planning and Review Committee. Environmental Scan 2013 - ACRL. Retrieved from

http://www.ala.org/acrl/sites/ala.org.acrl/files/content/publications/whitepapers/ EnvironmentalScan13.pdf

ARL. (2012). Code of Best Practices in Fair Use for Academic and Research Libraries. Retrieved from http://www.arl.org/storage/documents/publications/code-of-bestpractices-fair-use.pdf

Albitz, R.S. (2013). Copyright information management and the university library: Staffing, organizational placement and authority. Journal of Academic Librarianship, 39(5), 429-435.

Bailey, E.C. (2010). Educating future academic librarians: An analysis of courses in academic librarianship. Journal of Education for Library and Information Science, 51(1), 30-42.

Bell, S. (2008, June 10). What an academic librarianship course should offer. Message posted to http://acrlog.org/2008/06/10/what-an-academic-librarianship-course

Buchanan, E.A. (2004). Ethics in library and information science: What are we teaching? Journal of Information Ethics, 13(1), 51-60.

Burnett, P. (2013). Challenges and problems of library and information science education in selected African countries. Oxford: International Network for the Availability of Scientific Publications. Retrieved from http://library.ifla.org/175/1/199-burnett-en.pdf 
Cambridge University Press, Oxford University Press, Inc., Sage Publications, Inc. versus Carl V. Patton, et al. United States Court of Appeals for the Eleventh Circuit. 17 Oct. 2014. N.p., n.d. Web. <http://media.ca11.uscourts.gov/opinions/pub/files/201214676.pdf>.

Chu, H. (2010). Library and information science education in the digital age. In A. Woodsworth (Ed.), Advances in Librarianship, Volume 32: Exploring the Digital frontier, (pp. 77-112). New York: Emerald.

Charbonneau, D.H., \& Priehs, M. (2014). Copyright awareness, partnerships, and training issues in academic libraries. The Journal of Academic Librarianship, 40(3-4), 228-233.

Davis-Kahl, S., \& Hensley, M. (2013). Common ground at the nexus of information literacy and scholarly communication. Retrieved from http://www.ala.org/acrl/sites/ala.org.acrl/files/content/publications/booksanddigit alresources/digital/commonground_oa.pdf

Dragich, M.J. (1989). Information malpractice: Some thoughts on the potential liability of information professionals. Information Technology and Libraries, 8(3), 265272.

Educause (2013). Copyright challenges in a MOOC environment. Retrieved from https: / / net.educause.edu/ir/library/pdf/PUB9014.pdf

Gathegi, J.N., \& Burke, D.E. (2008). Convergence of information and law: A comparative study between i-schools and other ALISE schools. Journal for Library and Information Studies, 49(1), 1-22.

Hansen, D.H., Cross, W.M., \& Edwards, P.M. (2013). Copyright policy and practice in electronic reserves among ARL libraries. College \& Research Libraries, 74(1), 69-84. http://crl.acrl.org/content/74/1/69.abstract

Johnston, N., \& Williams, R. (2015). Skills and knowledge needs assessment of current and future library professionals in the state of Qatar. Library Management, 36(1/2), 86-98.

McCaslin, D. (2009). Access services education in library and information science programs. Journal of Access Services, 6(4), 485-496.

http://dx.doi.org/10.1080/15367960903149409

Peet, Lisa. (2014) Harvard's Copyright First Responders to the Rescue. Library Journal. August 13,2014. Retrieved from http://lj.libraryjournal.com/2014/08/copyright/harvards-copyright-firstresponders-to-the-rescue\# 
Sutton, S.W. (2009). Formal education in work with continuing resources: Do barriers really exist? Journal of Education for Library and Information Science, 50(3), 143-151.

Swain, N.K. (2003). Copyright as an elective at master's level curriculum: A proposal for LIS schools. Herald of Library Science, 42(1/2), 49-54.

Weber, B.M. (1975). Education of serials librarians: A survey. Drexel Library Quarterly, 11(3), 72-81. 